\title{
In memoriam \\ Adolf Primmer
}

(23. 2. $1931-9.7 .2011)$

\section{MANIBUS ADOLPHI}

Plautum, Vergilium, Ciceronem iuraque Romae perscrutans multis plurima Tute dabas.

Linquis multa tamen: psalmorum mystica verba, Hipponensis apex quae satis explicuit, aptius eduntur nunc Te duce Teque favente caelitus edentur: vivis enim ingenio! 
